ВПЛИВ РОЗВИТКУ ЦІННІСНО-МОТИВАЦІЙНОГО КРИТЕРІЮ

НА ЗАНЯТТЯХ ІНОЗЕМНОЇ МОВИ ФАРМАЦЕВТИЧНОГО ЗВО

В ПРОЦЕСІ ПРОФЕСІЙНОЇ ПІДГОТОВКИ НА ВИНИКНЕННЯ РИС, ПРИТАМАННИХ КОНКУРЕНТОСПРОМОЖНОСТІ У СТУДЕНТІВ

\title{
THE INFLUENCE OF THE DEVELOPMENT OF THE VALUE-MOTIVATIONAL CRITERION DURING FOREIGN LANGUAGE CLASSES OF THE PHARMACEUTICAL HIGHER EDUCATIONAL INSTITUTION IN THE COURSE OF PROFESSIONAL TRAINING ON OCCURRENCE OF THE FEATURES INHERENT IN COMPETITIVENESS OF STUDENTS
}

\begin{abstract}
Стаття присвячена одній з актуальних проблем підготовки майбутніх конкурентоспроможних фрахівців фрармацевтичної ссрери у фрармацевтичному закладі вищої освіти шляхом розвитку ціннісно-мотиваційного компоненту як критерію ціннісних орієнтацій, мотивів, які актуалізують потребу в саморозвитку особистості. Зокрема, існує необхідність підготовки фрахівців фрармачевтичної галузі, конкурентоспроможних на ринку праці, які будуть мати змогу прийняти рішення у складних ситуаціях. Основна увага зосереджується на теоретичному аналізі наукових джерел для висвітлення стану розробленості проблеми конкурентоспроможності студентів вищих освітніх закладів; моделюванні, яке дало змогу охарактеризувати модель підвищення конкурентоспроможності майбутніх фахівців фрармацевтичної сфери у процесі профеесійної підготовки та критеріїв їі сорормованості; емпіричних дослідженнях - анкетуванні, тестуванні, спостереженнях та методах математичної статистики. Висвітлюється зростання рівня ссрормованості конкурентоспроможності майбутніх орармацевтів за ціннісномотиваційним критерієм й усіма його показниками в експериментальній групі після завершення формувального експерименту, що свідчить про ефрективність використовуваних організаційно-педагогічних умов формування конкурентоспроможності майбутніх фрармацевтів. На основі аналізу проблеми конкурентоспроможності на тлі розвитку ціннісно-мотиваційного критерію на заняттях іноземної мови фрармацевтичного закладу вищої освіти у процесі професійної підготовки на виникнення конкурентоспроможних рис у майбутніх фрахівців у цій статті на підставі аналізу математичної обробки презентовано авторське бачення на підвищення конкурентоспроможності студентів після організаційно-педагогічного експерименту, яка є необхідною властивістю для участі у фармачевтичній сфрері діяльності. Дослідження мають великі перспективи подальшого поглиблення.
\end{abstract}

Ключові слова: конкурентоспроможність, конкуренція, конкурентоспроможний фрахівець, ціннісно-мотиваційний критерій, фрармацевтична галузь.

The article is devoted to one of the urgent problems of training future competitive specialists in the pharmaceutical field in a pharmaceutical institution of higher education through the development of value-motivational component as a criterion of value orientations, motives that actualize the need for self-development. In particular, there is a need to train pharmaceutical professionals competitive in the labor market who will be able to make decisions in difficult situations. The main focus is on theoretical analysis of scientific sources to highlight the state of development of the problem of competitiveness of higher education students; modeling, which allowed to characterize the model of increasing the competitiveness of future specialists in the pharmaceutical field in the process of professional training and the criteria for its formation; empirical research - questionnaires, testing, observations and methods of mathematical statistics. The growth of the level of competitiveness of future pharmacists according to the value-motivational criterion and all its indicators in the experimental group after the completion of the formative experiment, which indicates the effectiveness of the organizational and pedagogical conditions for the competitiveness of future pharmacists. Based on the analysis of the problem of competitiveness against the background of the development of value-motivational criteria in foreign language classes of a pharmaceutical higher educational institution in the process of training for the emergence of competitive traits in future professionals in this article on the basis of analysis of the mathematical processing experiment, which is a necessary property for participation in the pharmaceutical field. Research has great prospects for further deepening.

Key words: competitiveness, competition, competitive specialist, value-motivational criterion, pharmaceutical industry.
Постановка проблеми. На сучасному етапі для розвитку рис, притаманних конкурентоспроможності, вища освіта України потребує глобальних змін з метою подальшого успішного існування та шансу зайняти почесне місце на міжнародному рівні освітніх послуг, з цього вітчизняні заклади вищої освіти (далі - ЗВО) повинні значно підвищити свою конкурентоспроможність. У статті висвітлені основні положення підвищення конку- рентоспроможності вищої освіти України в умовах вливання фрармацевтичного бізнесу в економіку .

Актуальністю цієї проблеми $є$ необхідність підготовки фрахівців фрармацевтичної галузі, конкурентоспроможних на ринку праці, які матимуть змогу прийняти рішення у складних ситуаціях.

Аналіз останніх досліджень і публікацій. Проблемам удосконалення системи вищої освіти присвячені праці українських вчених М. Ванієвої, 
С. Єрохіна, І. Лук'яненко та інших. Величезний внесок у пояснення питань підвищення конкурентоспроможності майбутніх фрахівців закладів вищої освіти здійснили такі вітчизняні вчені, як В. Бобров, В. Гриньова, В. Кремень, І. Сазонець та інші. В. Андреєв, Г. Ібрагімова, Н. Ничкало розкрили процес формування конкурентоспроможності майбутніх фрахівців в педагогічних аспектах з проблем педагогіки профресійної освіти. Питання конкурентоспроможності та конкуренції розглянуто у працях В. Васильченко, Г. Дмітренко, Т. Заяць, Л. Лісогор. 3 точки зору психології становлення конкурентоспроможності фрахівців окреслено в роботах Л. Лазаревої, Л. Мітіної, Е. Хайрулліної.

Інноваційні процеси у взаємозв'язку 3 конкуренцією досліджуються такими вітчизняними вченими, як Ю. Бажал, В. Вишневський, В. Гейц, А. Землянкін та зарубіжними науковцями - І. Адізез, Н. Блум, К. Ерроу, Р. Нельсон, Й. Шумпетер.

Виділення не вирішених раніше частин загальної проблеми. Однак досить мало уваги приділено інноваційним методам, які сприяють підвищенню конкурентоспроможності студентів у ЗВО. Інноваційний розвиток є складним процесом, який залежить від багатьох внутрішніх та зовнішніх для суб'єктів навчання чинників.

Актуальність зазначеної проблеми посилюється необхідністю усунення суперечностей, що впливають на якість професійної підготовки майбутніх фрахівців фрармацевтичної галузі.

Це суперечності між:

- потребою суспільства у конкурентоспроможних фрахівцях фрармацевтичної галузі та незадовільними професійними якостями, які характеризують їхню конкурентоспроможність;

- сучасними вимогами ринку праці та недостатніми можливостями ЗВО для підготовки висококонкурентоздатних випускників;

- потребами особистості у такому професійно-інтелектуальному розвитку, який забезпечить її конкурентоспроможність на ринку праці, та методично недостатньою теорією й технологією підготовки фрахівців у фрармацевтичних вищих закладах;

- потребою правильного оцінювання рівня конкурентоспроможності фрахівців фрармацевтичної галузі й недостатньо розробленими методами вимірювання їхніх досягнень.

Подолання цих суперечностей можливе за умови розробки інструментарію, який дозволить об'єктивно оцінювати рівень конкурентоспроможності студентів, та впровадження цього інструментарію у навчальний процес підготовки майбутніх фрахівців фрармацевтичної сорери.

Незважаючи на наявність величезної праці великої кількості вчених 3 цього питання, необхідність розв'язання цих проблем обумовила мету та завдання цієї статті.
Ціль дослідження ґрунтується на пошуці умов, при яких суб'єкт буде фрормуватися як конкурентоспроможний фрахівець у процесі профресійної діяльності.

Мета дослідження полягає у виявленні теоретично обґрунтованих організаційно-педагогічних умов, з існуванням яких у ЗВО буде фрормуватися конкурентоспроможність майбутнього фрахівця фрармацевтичної галузі в процесі профресійної підготовки.

Об'єкт дослідження - якість професійної підготовки у ЗВО майбутніх фрахівців фрармацевтичної сорери

Предмет дослідження - організаційно-педагогічні умови, які сприяють фрормуванню конкурентоспроможності майбутніх фрахівців фрармацевтичної галузі в процесі професійної підготовки.

Гіпотеза дослідження ґрунтується на припущенні, що процес підготовки майбутніх фрахівців фрармації до професійної діяльності буде відбуватися більш успішно завдяки розвитку ціннісномотиваційного критерію, реалізацією такої організаційно-педагогічної умови, як імітація виробничих ситуацій з фармацевтичної сфери на заняттях іноземної мови у процесі професійної підготовки.

Для реалізації зазначеної мети цього дослідження було визначено низку таких завдань:

- дослідити специфріку понять «конкурентоспроможність», «конкурентоспроможність фрахівця», «конкуренція»;

- дати формулювання ціннісно-мотиваційного критерію як компоненту моделі підвищення конкурентоспроможності фрахівця орармацевтичної сорери;

- проаналізувати результати експериментальної роботи за ціннісно-мотиваційним критерієм.

Методи дослідження. Для того, щоб досягнути мети й вирішити завдання дослідження, було використано методи теоретичного аналізу наукових джерел для висвітлення стану розробленості проблеми конкурентоспроможності студентів вищих освітніх закладів; моделювання, яке дало змогу охарактеризувати модель підвищення конкурентоспроможності майбутніх фрахівців фрармацевтичної сорери у процесі професійної підготовки та критеріїв її сорормованості; емпіричні - анкетування, тестування, спостереження та методи математичної статистики.

Виклад основного матеріалу. Для вдосконалення сутності понять «конкурентоспроможність», «конкурентоспроможність фрахівця» та «конкуренція» звернемося до класичних праць таких вчених, як Г. Мороз [2, с. 11], яка трактує конкурентоспроможність як здатність до конкуренції, боротьбу за досягнення найвищих результатів, а [3, с. 66] «конкурентоспроможність фрахівця» висловлює в таланті, здатності особистості витримати конкуренцію. 
В. Бикова [1, с. 9] стверджує, що «конкурентоспроможність фахівця» - це перевага конкретного фрахівця перед іншими фрахівцями, що виконують аналогічні трудові операції в прояві якостей, властивостей, результатів власної трудової діяльності, найбільш значущих для забезпечення лідерства фірми, організації, де він працює.

Суть конкуренції у М. Портера [4, с. 53] виражена загрозоюпояви товарів-замінників, здатність постачальників комплектуючих виробів торгуватися і суперництво вже наявних конкурентів між собою.

Конкуренція 3 точки зору економістів трактується А. Смітом [5, с. 13] як поведінкова категорія, коли індивідуальні продавці та покупці суперничають на ринку праці за більш вигідні умови продажі і покупки відповідно.

Й. Шумпетер [6, с. 34] трактує конкуренцію як суперництво старого з новим - інноваціями. Отже, конкурентоспроможність - це здатність до конкуренції, боротьба за найкращі результати, а конкурентоспроможна людина - це особистість, яка має змогу витримати конкуренцію.

Конкурентоспроможність майбутнього фахівця фармацевтичної сфери можливо означити як показник якості підготовки закладом вищої освіти молодих фахівців. Для цього у ЗВО повинні бути умови для розвитку ціннісно-мотиваційного критерію, який складається з ціннісних орієнтацій, мотивів спрямованості, які актуалізують потребу в самоактуалізації та саморозвитку особистості; він $€$ важливим критерієм конкурентоспроможності для розвитку його складових на заняттях іноземної мови у процесі професійної підготовки, оскільки він, ціннісно-мотиваційний компонент конкурентоспроможності, містить різні види мотивів у процесі профресійної підготовки майбутніх фрахівців фрармацевтичної галузі: розуміння профрільної компетентності, готовність та прагнення до прояву компетентності, ціннісне ставлення до професіональної фрахової діяльності й особистісного зростання, що забезпечує сфрормованість соціальних мотивів, особистісного та профресій- ного зростання, пізнавальний інтерес до набуття нових знань, формування фахових умінь, мотивацію на успіх у навчанні, потреб в саморозвитку й самовираженні.

3 метою перевірки ефрективності розробленої нами моделі підвищення конкурентоспроможності майбутнього фахівця фрармацевтичної галузі викладачами кафредри іноземних мов Національного фрармацевтичного університету (далі - НФаУ) був проведений організаційно-педагогічний експеримент, який тривав упродовж 2008-2016 рр. За цей період на різних етапах експериментальною роботою було охоплено 540 студентів НФаУ і 60 викладачів. 3 них пілотним дослідженням було охоплено 370 студентів і 56 викладачів.

Після математичного опрацювання зібраних емпіричних даних результати діагностичного контрольного зрізу сфрормованості основних показників конкурентоспроможності майбутніх фрармацевтів за, на мій погляд, компонентами, найбільш важливими для процесу формування конкурентоспроможності майбутніх молодих спеціалістів за ціннісно-мотиваційним критерієм, виглядають таким чином: з 370 студентів експериментальної групи високий рівень мали 15,1\% студентів, середній - 43\%, низький $-41,9 \%$. У контрольній групі (КГ) високий рівень мали 10,2\% студентів, середній - 30\%, низький - 59,8\%. (аналіз за загальним результатом). Відповідно, показники, отримані на першому етапі експерименту, були такими: в експериментальній групі (ЕГ) високий рівень мали $10,8 \%$ студентів, середній - 29,9\%, низький $59,3 \%$. У контрольній групі високий рівень мали $8,3 \%$, середній - 27,2\%, низький - 64,5\%. Отримані результати зведені в Таблиці 1.

Попередній аналіз даних, наведених у таблиці 1 , показує, що за всіма показниками результати діагностичного контрольного зрізу для студентів контрольної (КГ) та експериментальної (ЕГ) груп до проведення дослідно-експериментальної роботи були близькими за значеннями, а після її проведення відповідні результати для сту-

Результати діагностики сформованості конкурентоспроможності майбутніх фармацевтів за ціннісно-мотиваційним критерієм після завершення формувального експерименту

\begin{tabular}{|c|c|c|c|c|c|c|c|c|c|c|c|c|}
\hline \multirow{4}{*}{ Показники критерію } & \multicolumn{6}{|c|}{$\%$} & \multicolumn{6}{|c|}{$\%$} \\
\hline & \multicolumn{3}{|c|}{ КГ } & \multicolumn{3}{|c|}{ EГ } & \multicolumn{3}{|c|}{ КГ } & \multicolumn{3}{|c|}{ ЕГ } \\
\hline & \multicolumn{6}{|c|}{$\begin{array}{c}\text { до дослідно-експериментальної } \\
\text { роботи }\end{array}$} & \multicolumn{6}{|c|}{$\begin{array}{c}\text { після дослідно-експериментальної } \\
\text { роботи }\end{array}$} \\
\hline & B & C & $\mathbf{H}$ & B & C & $\mathrm{H}$ & B & C & $\mathbf{H}$ & B & C & $\mathbf{H}$ \\
\hline $\begin{array}{l}\text { задоволеність діяльністю за про- } \\
\text { фресійним спрямуванням }\end{array}$ & 8,4 & 25,9 & 65,7 & 10,6 & 28,1 & 61,3 & 10,3 & 28,7 & 61 & 15,2 & 41,7 & 43,1 \\
\hline $\begin{array}{l}\text { наявність мотивів до успіху в кон- } \\
\text { курентоспроможного фрармацевта }\end{array}$ & 8,6 & 28,6 & 62,8 & 10,9 & 30,7 & 58,4 & 10,5 & 31,4 & 58,1 & 15,4 & 44,4 & 40,2 \\
\hline $\begin{array}{l}\text { наявність мотивів до уникнення } \\
\text { невдач у конкурентоспроможного } \\
\text { фрармацевта }\end{array}$ & 7,9 & 27,1 & 65 & 10,7 & 30,9 & 58,4 & 9,8 & 29,9 & 60,3 & 14,7 & 42,9 & 42,4 \\
\hline Разом: & 8,3 & 27,2 & 64,5 & 10,8 & 29,9 & 59,3 & 10,2 & 30 & 59,8 & 15,1 & 43 & 41,9 \\
\hline
\end{tabular}




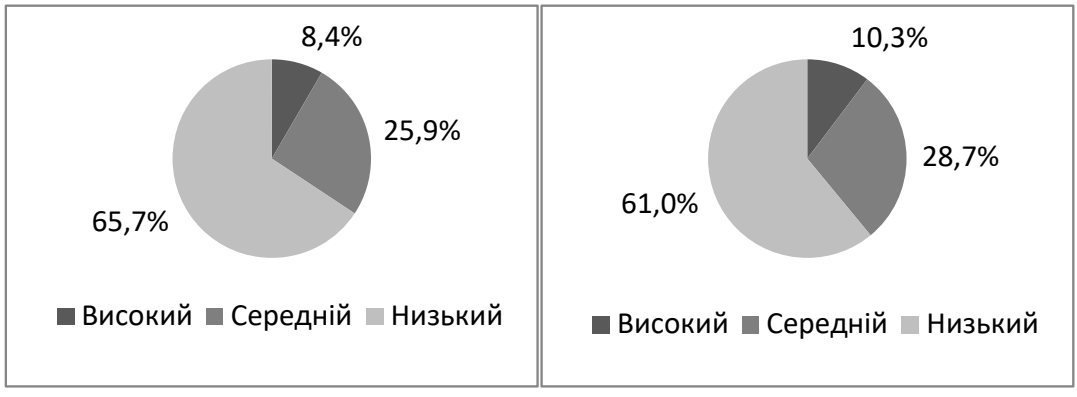

a)

б)

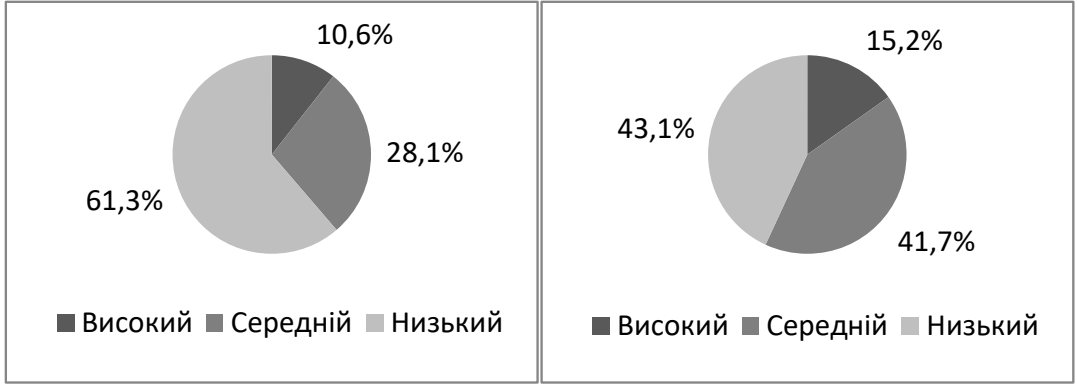

B)

г)

Рис. 1. Результати діагностики за показником «задоволеність діяльністю за професійним спрямуванням» ціннісно-мотиваційного критерію для КГ до (а) та після (б) проведення

дослідно-експериментальної роботи і для ЕГ до (в) та після

(г) проведення дослідно-експериментальної роботи

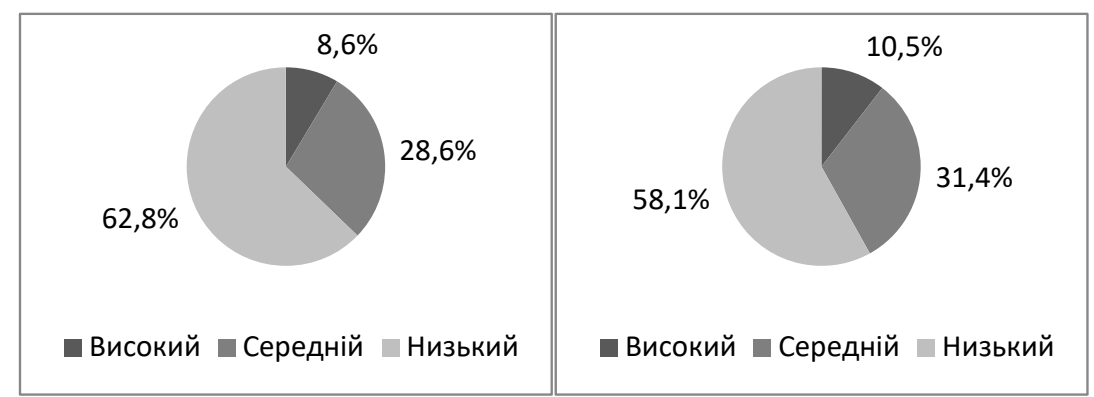

a)

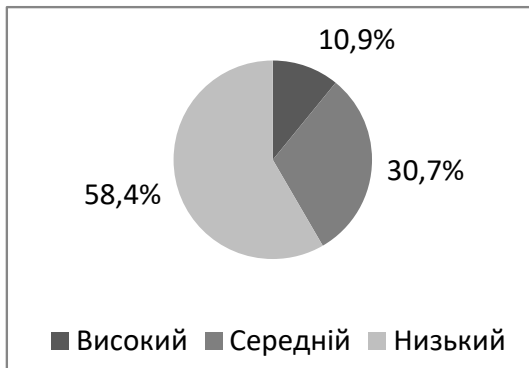

B) б)

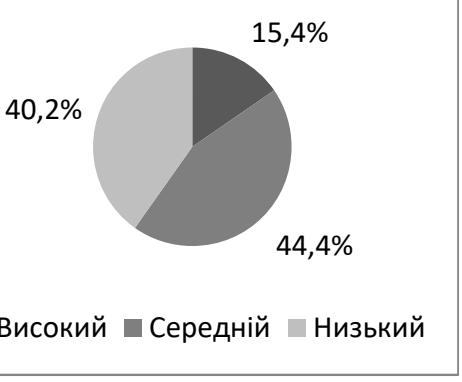

г)

Рис. 2. Результати діагностики за показником «наявність мотивів до успіху в конкурентоспроможного фармацевта» ціннісномотиваційного критерію для КГ до (а) та після (б) проведення дослідно-експериментальної роботи і для ЕГ до (в) та після

(г) проведення дослідно-експериментальної роботи 


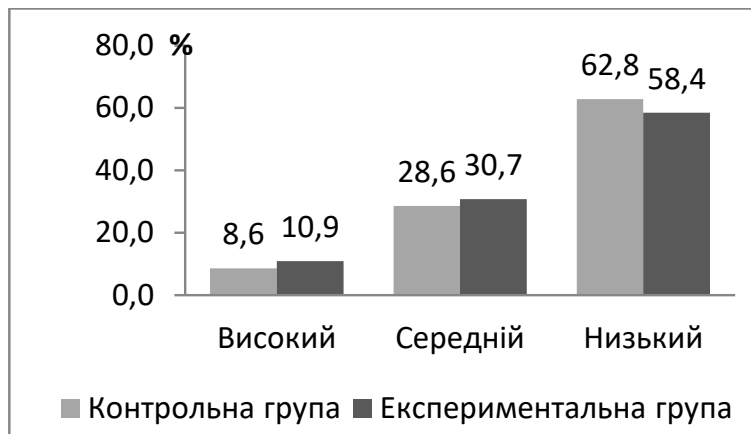

a)

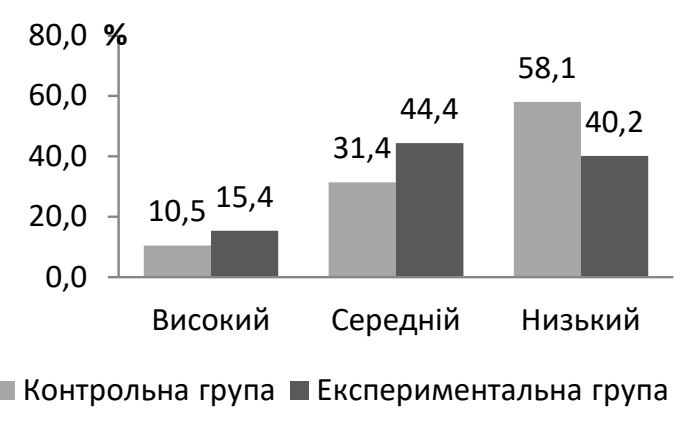

б)

Рис. 3. Порівняння результатів діагностики за показником «наявність мотивів до успіху в конкурентоспроможного фармацевта» ціннісно-мотиваційного критерію для студентів КГ та ЕГ до (а) та після (б) проведення дослідно-експериментальної роботи

дентів експериментальної групи стали кращими за результати контрольної групи.

На рисунках 1-3 зображені графрічні ілюстрації даних таблиці 1, що дозволяє спростити порівняльний аналіз результатів діагностики контрольної та експериментальної груп та робить наведену інорормацію більш наочною.

Післязавершенняформувальногоексперименту, як свідчить аналіз загального результату, в експериментальній групі спостерігається значне покращення відсоткового показника, який характеризує кількість студентів з високим та середнім рівнями, та скорочення кількості студентів з низьким рівнем.

У зв'язку з цим, констатоване зростання рівня сорормованості конкурентоспроможності майбутніх фрармацевтів за ціннісно-мотиваційним критерієм й усіма його показниками в експериментальній групі після завершення фрормувального експерименту свідчить про есрективність використовуваних нами педагогічних умов фрормування конкурентоспроможності майбутніх фармацевтів.

Висновки. Щодо проблеми конкурентоспроможності на тлі розвитку ціннісно-мотиваційного критерію на заняттях іноземної мови фрармацевтичного закладу вищої освіти у процесі професійної підготовки на виникнення конкурентоспроможних рис у майбутніх фрахівців у цій статті, на підставі аналізу математичної обробки, презентовано авторський погляд на підвищення конкурентоспроможності студентів після організаційнопедагогічного експерименту, яка $€$ необхідною властивістю для участі у фрармацевтичній сорері діяльності. У результаті експерименту за ціннісномотиваційним критерієм у студентів показане підвищення конкурентоспроможності та конста- товане значне покращення особистісних характеристик, які мають риси конкурентоспроможності.

Теоретичне і практичне значення проведеного дослідження полягає у можливості використання отриманих результатів у ході проєктування організаційно-педагогічного процесу для росту конкурентоспроможності фрахівців.

Перспективи подальших розвідок убачаємо в розробці навчально-методичного забезпечення супроводу майбутніх фрармацевтів на шляху самовдосконалення і здобуття їхньої професійної компетентності для яскравої профресійної діяльності на міжнародному ринку праці.

\section{БІБЛІОГРАФІЧНИЙ СПИСОК:}

1. Бикова В. Рефлексія. Вісник Дніпропетровського університету імені Альфреда Нобеля. Серія: Педагогіка і психологія. 2012. № 1 (3). С. 9.

2. Мороз Г. Компоненты и условия, способствующие формированию конкурентоспособности будущих специалистов фармацевтической сферы в процессе профрессиональной подготовки в учреждении высшего образования и результаты эксперимента по личностно-деятельностному критерию. Достижения и проблемы современной науки. Научный журнал «GLOBUS». Санкт-Петербург : GLOBUS, 2020. № 8 (54). C. 8-15.

3. Moroz G. N. Formation of Future Specialists' competitiveness in the Pharmaceutical Field in Professional training. Education. Psychology. Philology. (Literary Studies): BarSU Herald. 2019. № 7. P. 65-70.

4. Портер М. Международная конфреренция / Международные отношения, 1996. 896 с.

5. Смит А. Исследование о природе и причинах богатства народов. Москва : Ось-89, 1997. 255 с.

6. Шумпетер Й. Теория экономического развития. Москва : Прогресс, 1982. 244 с. 